\title{
UJI EFEKTIVITAS ANTI INFLAMASI SALEP EKSTRAK RIMPANG KENCUR (Kaempferia galanga L) TERHADAP LUKA SAYAT PADA TIKUS JANTAN
}

\author{
${ }^{1}$ Rizki Rahmah Fauzia,S.Farm.,M.HKes.,Apt. \\ ${ }^{2}$ Siti Pandan Wangi TW, M.M., Apt. \\ ${ }^{3}$ Imas Sulastri \\ ${ }^{1}$ Sekolah Tinggi Farmasi YPIB Cirebon (kikirahmah88@gmail.com, \\ ${ }^{2}$ Akademi Farmasi Muhammadiyah Cirebon (sitipandanwangitw@yahoo.com) \\ ${ }^{3}$ Sekolah Tinggi Farmasi YPIB Cirebon (imaceae56@gmail.com)
}

\begin{abstract}
ABSTRAK
Rimpang kencur (Kaempferia galanga $\mathrm{L}$ ) tanaman dari keluarga zingiberaceae ini memiliki kandungan senyawa minyak atsiri, flavonoid dan saponin yang telah banyak diteliti dan diketahui berkhasiat sebagai antiinflamasi (radang/bengkak). Formula yang dikembangkan pada penelitian ini adalah bentuk sediaan topikal salep dengan menggunakan basis hidrokarbon (Vaselin flavum) dan pengawet (Nipagin). Penelitian ini bertujuan untuk mengetahui efektivitas antiinflamasi terhadap luka sayat pada tikus putih jantan dan uji stabilitas sediaan salep ekstrak rimpang kencur dengan konsentrasi 5\%, $10 \%, 15 \%$, basis salep (kontrol negatif) dan betadine salep (kontrol positif). Ekstrak kental rimpang kencur diperoleh dengan proses maserasi. Sediaan salep kemudian dievaluasi sifat fisiknya, meliputi homogenitas, daya sebar, daya lekat, $\mathrm{pH}$ dan uji iritasi. Penelitian ini menggunakan 15 ekor tikus putih jantan yang terlebih dahulu dicukur bulu pada bagian punggungnya kemudian dibuat luka dengan panjang $\pm 2 \mathrm{~cm}$ dan kedalaman $2 \mathrm{~mm}$, hewan uji dibagi menjadi 5 kelompok dan luka diolesi salep setiap pagi dan sore. Hasil uji stabilitas salep menunjukkan bahwa sediaaan salep rimpang kencur memenuhi syarat sediaan yang baik kecuali daya sebar. Data hasil percobaan uji efektivitas yang diperoleh kemudian dianalisis secara statistik dengan taraf kepercayaan 95\%. Hasil uji statistik dengan uji ANAVA menunjukkan $F_{\text {hitung }}$ lebih besar dari $F_{\text {tabel }}(3,043>2,450)$ artinya salep ekstrak rimpang kencur (Kaempferia galanga L) mempunyai efektivitas sebagai antiinflamasi pada luka sayat tikus putih jantan yang tidak berbeda nyata dengan kontrol positif yaitu betadine salep.
\end{abstract}

Kata kunci : Salep ekstrak rimpang kencur, antiinflamasi, luka sayat.

\begin{abstract}
This plant from family zingiberaceae, Kaempferiae galanga L. has chemical compound such as essential oil, flavonoid, and saponin which have already tested and know as anti-inflammation. This study aimed to developed a hydrocarbon ointment that
\end{abstract}


use vaselin flavum and nipagin as preservation. This study also aimed to find out effectiveness Kaempferiae galanga $\mathrm{L}$ as anti-inflammation for slice injury experimental mouse and stability test extract Kaempferiae galanga L ointment with consentration 5\%, $10 \%, 15 \%$, ointment base (negative control), and betadine ointment (positive control). Extract Kaempferiae galanga $\mathrm{L}$ is taken by process maseration. Then, ointment extract is evaluated by physicly such as homogenity, spread out test, sticky test, ph, and iritation test. This study us 15 experimental mouse that was cut its hair before than make the injury slice within $2 \mathrm{~cm}$ and $2 \mathrm{~mm}$. It divided into 5 groups and spread ointment every morning and afternoon. Result of experiment is ointment have a good quality expect spread out test. From the result also have ANAVA test that showed $\mathrm{Fh}>\mathrm{Ft}(3,043>2,450)$ means the ointment have effectiveness as anti-inflammation to injury's slice of experimental mouse that has no different from betadine ointment as positive control.

Keyword : Kaempferia Rhizome extract ointment, anti-inflammation, injury slice.

\section{PENDAHULUAN}

Inflamasi adalah mekanisme respon tubuh terhadap kerusakan seluler. Tanpa respon inflamasi, tubuh kita tidak dapat bertahan hidup. Oleh karena itu, inflamasi adalah mekanisme protektif yang dirancang untuk membersihkan tubuh dari penyebab cedera dan mempersiapkan jaringan tubuh kita untuk membentuk kembali jaringan yang mengalami cedera. Respon inflamasi adalah reaksi lokal yang melibatkan pelepasan substansi antibakteri yang menjaga tubuh dari serangan zat asing. Proses inflamasi membatasi area cedera sehingga toksin tidak dapat mempengaruhi keseluruhan sistem. Akhirnya, proses inflamasi menempatkan infrastruktur yang memungkinkan tubuh sembuh dengan sendirinya dan kembali berfungsi secara normal. Dalam beberapa aspek, inflamasi dapat dideskripsikan sebagai mekanisme homeostatis. Tanda dan gejala utama inflamasi adalah kemerahan, nyeri, bengkak, panas, dan hilangnya fungsi (Barber, 2012)

Obat modern yang biasa digunakan sebagai antiinflamasi adalah obat golongan AINS (Antiinflamasi Non Steroid) yang pada umumnya mempunyai efek samping tukak lambung sehingga perlu dicari pengobatan alternatif untuk melawan dan mengendalikan rasa nyeri dan peradangan dengan efek samping yang relatif lebih kecil, misalnya obat yang berasal dari tumbuhan (Narande Julia M, 2013). Secara empirik, kencur dikenal berkhasiat sebagai obat untuk pengompres bengkak/radang, pegal-pegal, batuk, gatalgatal pada tenggorokan, perut kembung, mual, masuk angin, tetanus dan penambah nafsu makan.

Menurut penelitian lain menyatakan bahwa tanaman kencur khususnya bagian rimpang dapat digunakan sebagai antiinflamasi. Rimpang kencur mengandung flavonoid, 
saponin dan minyak atsiri yang dapat berfungsi sebagai antiinflamasi. Antiinflamasi pada kencur merupakan tipe anti inflamasi non steroid. Flavonoid dapat menghambat jalur metabolisme asam arakidonat, pembentukan prostalglandin dan pelepasan histamine pada radang. Saponin bersifat seperti detergen diduga mampu berinteraksi dengan banyak membrane lipid seperti fosfolipid yang merupakan perkusor prostalglandin mediatormediator inflamasi lainnya. Minyak atsiri dapat menghambat agregasi platelet dengan cara menghambat pembentukan tromboksan sehingga juga berperan dalam efek antiinflamasi (Hasanah Aliya N, 2011).

Terapi topikal merupakan salah satu metode pengobatan yang sering digunakan dalam bidang dermatologis. Contohnya salep, salep merupakan sediaan semi solid yang dapat digunakan pada kulit maupun mukosa. Kelebihan dari sediaan salep ini adalah mempunyai bentuk yang lunak, halus, homogen, dan mudah dioleskan, sehingga dapat digunakan untuk kulit yang teriritasi, inflamasi dan ekskoriasi, sebagai bahan pembawa substansi obat untuk pengobatan kulit, sebagai bahan pelumas pada kulit, sebagai pelindung untuk kulit (mencegah kontak permukaan kulit dengan larutan berair) dan sebagai obat luar (Asmara, 2012). Dalam sebuah jurnal penelitian yang dilakukan oleh (Buang, 2012) bahwa ekstrak etanol rimpang kunyit dalam bentuk sediaan salep dengan konsentrasi $4 \%$ dapat memberikan efek antiinflamasi yang tidak berbeda nyata dengan kontrol positifnya.

Berdasarkan latar belakang diatas, maka penulis tertarik melakukan penelitian uji efektivitas antiinflamasi dari rimpang kencur dengan judul "Uji Efektivitas Anti Inflamasi Salep Ekstrak Rimpang Kencur (Kaempferia galanga L) Terhadap Luka Sayat Pada Tikus Jantan".

\section{METODE PENELITIAN}

Penelitian ini telah dilakukan dari bulan Februari 2017 sampai April 2017 di Sekolah Tinggi Farmasi YPIB Cirebon. Jenis penelitian yang digunakan adalah eksperimen. Jenis penelitian ini digunakan untuk melakukan suatu percobaan (experiment research) yang bertujuan untuk mengetahui suatu gejala atau pengaruh yang timbul terhadap variabel eksperimen, sebagai akibat dari adanya perlakuan tertentu dari suatu percobaan (Supardi, 2014). 
Bahan yang digunakan dalam penelitian ini yaitu rimpang kencur (Kaempferia galanga L), etanol 70\%, vaselin flavum, metil paraben (Nipagin), aquadest, dan betadine salep. Hewan percobaan yang digunakan pada penelitian ini adalah tikus jantan putih sebanyak 15 ekor dengan bobot 180-200 gram.

\section{Pembuatan Ekstrak Rimpang Kencur}

Pada penelitian ini, ekstraksi rimpang kencur (Kaempferia galanga L) dilakukan menggunakan metode maserasi. Simplisia rimpang kencur yang sudah dihaluskan sebanyak 100 gram diekstraksi menggunakan etanol $70 \%$ sebanyak $750 \mathrm{ml}$. proses maserasi dilakukan di dalam maserator selama 5 x 24 jam sambil sesekali diaduk. Maserat yang didapat disaring dengan kain flanel (filtrat 1) dan sisanya diekstrak kembali dengan etanol 70\% sebanyak $250 \mathrm{ml}$ selama 2 x 24 jam lalu disaring(filtrat 2). Filtrat 1 dan filtrat 2 dikumpulkan lalu diuapkan dengan menggunakan evaporator hingga menjadi ekstrak kental.

\section{Pembuatan Salep Ekstrak Rimpang Kencur}

Tabel 1. Formulasi Konsentrasi Salep

\begin{tabular}{ccc}
\hline \multicolumn{3}{c}{ Formulasi Konsentrasi Salep } \\
\hline $\mathbf{5 \%}$ & $10 \%$ & $15 \%$ \\
\hline R/ Eks.Rimp.Kencur & R/ Eks.Rimp.Kencur 10\% & R/ Eks.Rimp.Kencur 15\% \\
$\mathbf{5 \%}$ & Nipagin 0,1 \% & Nipagin 0,1\% \\
Nipagin 0,1 \% & Vaselin flavum ad 75 g & Vaselin flavum ad 75 g \\
Vaselin flavum ad & M.F.Ungt & M.F.Ungt \\
$\mathbf{7 5}$ g M.F.Ungt & & \\
\hline
\end{tabular}

Sumber : basis salep (anonim, 1978), pengawet nipagin (Agoes, 2007).

Cara pembuatan yaitu timbang semua bahan, masukkan sebagian vaselin flavum

ke dalam mortar dan gerus halus homogen. Tambahkan nipagin gerus ad homogen. Kemudian tambahkan esktrak kental sedikit demi sedikit dan gerus add homogeny lalu masukkan sisa bagian vaselin flavum dan gerus add homogen. Formulasi ini dibagi, disimpan dan dikemas dalam pot salep ukuran 5 gram, sehingga didapat 15 pot salep untuk setiap konsentrasinya.

\section{Pengujian Salep Ekstrak Rimpang Kencur}

Pengujian salep meliputi uji organoleptik dan stabilitas meliputi bentuk (tekstur), warna dan bau formulasi salep selama 1 bulan dengan data pengamatan dilakukan pada hari ke $1,7,14,21,28$ dan stabilitasnya pada suhu $0^{\circ} \mathrm{C}, 25^{\circ} \mathrm{C}$ (suhu kamar) dan $40^{\circ} \mathrm{C}$, uji pH, uji homogenitas, uji daya sebar, dan uji daya lekat (Naibaho, 2013) serta uji daya 
iritasi (menggunakan metode Draize test dengan penilaian iritasinya (Komala, 2015) adalah $0,00=$ tidak mengiritasi, $0,04-0,99=$ sedikit mengiritasi, $1,00-2,99=$ iritasi ringan, 3,00 - 5,99 = iritasi sedang, dan 6,00 - 8,00 = iritasi berat).

\section{Pengujian Anti Inflamsi Ekstrak Rimpang Kencur}

Tikus dibagi menjadi 5 kelompok, masing-masing kelompok terdiri dari 3 ekor tikus. Kelompok 1 untuk pengujian ekstrak 5\%, kelompok 2 untuk pengujian ekstrak 10\%, kelompok 3 untuk pengujian ekstrak 15\%, kelompok 4 untuk pengujian kontrol positif (betadine salep), dan kelompok 5 untuk pengujian kontrol negatif (basis salep ekstrak rimpang kencur). Masing-masing tikus dicukur bulunya secukupnya dibagian punggung kemudian dibuat luka sayat menggunakan bisturi dengan panjang $2 \mathrm{~cm}$ dan kedalaman $\pm 2 \mathrm{~mm}$. Setelah dibuat luka, masing-masing kelompok dioleskan tipis $\pm 0,5$ gram salep yang disebutkan di atas. Perlakuan tersebut dilakukan hingga sembuh dan dioleskan sehari dua kali pagi dan sore.

\section{Teknik Pengumpulan Data dan Analisis Data}

Sumber data didapatkan dari hasil pengamatan sebagai sumber data primer dan literatur buku ataupun hasil penelitian yang lain sebagai sumber data sekunder. Teknik pengolahan data yang digunakan dalam penelitian ini yaitu hasil pengamatan diolah secara statistik dengan menggunakan metode analisa variasi (ANAVA) satu arah dan dilanjut dengan uji $\mathrm{T}$.

\section{PEMBAHASAN}

Dari hasil determinasi tanaman menunjukkan bahwa bahan uji simplisia yang digunakan dalam penelitian ini adalah benar rimpang kencur (Kaempferiae galanga L) dengan nilai persentase rendemen ekstrak sebesar 34,07\%.

\section{Hasil Uji Salep Ekstrak Rimpang Kencur}

Uji organoleptis salep dilakukan untuk mengetahui warna, bentuk dan bau salep. Hasil uji organoleptis salep ekstrak rimpang kencur yaitu berbentuk semi solid, berwarna coklat muda pada konsentrasi 5\%, coklat pada konsentrasi 10\% dan 15\%, kuning untuk warna basis salep dan berbau khas kencur atau vaselin. Berdasarkan hasil uji organoleptis sediaan salep relatif stabil karena tidak terjadi perubahan bentuk, warna dan tidak mengalami perubahan bau setelah di uji pada suhu $0^{\circ} \mathrm{C}, 25^{\circ} \mathrm{C}$, dan $40^{\circ} \mathrm{C}$. 
PharmaXplore

Jurnal Sains dan Ilmu Farmasi
ISSN: $2527-5801$

Vol. 2 No 3 Mei 2017

Untuk uji $\mathrm{pH}$ berdasarkan hasil pengamatan yang dilakukan pada sediaan salep, kontrol positif dan kontrol negatif tidak mengalami perubahan $\mathrm{pH}$ yaitu memiliki pH 6 . Sediaan topikal yang baik yaitu memiliki $\mathrm{pH}$ yang sama dengan $\mathrm{pH}$ kulit normal yaitu 4,5-6,5 sehingga dari hasil uji $\mathrm{pH}$ ini aman pada penggunaan topikal sebagai sediaan salep antiinflamasi. Kesesuaian $\mathrm{pH}$ kulit dengan $\mathrm{pH}$ sediaan topikal mempengaruhi penerimaan kulit terhadap sediaan. Sediaan topikal yang ideal adalah tidak mengiritasi kulit. Kemungkinan iritasi kulit akan sangat besar apabila sediaan terlalu asam dan kulit akan kering jika terlalu basa.

Hasil uji homogenitas sediaan salep ekstrak rimpang kencur dari awal pembuatan sampai minggu ke-4 adalah sebagai berikut :

Tabel 2. Hasil Uji Homogenitas

\begin{tabular}{|c|c|c|c|c|c|c|c|}
\hline \multirow[t]{2}{*}{ Suhu } & \multirow[t]{2}{*}{ Sediaan } & \multicolumn{6}{|c|}{ Hari } \\
\hline & & 0 & 1 & 7 & 14 & 21 & 28 \\
\hline \multirow[t]{5}{*}{$\mathbf{0}^{\circ} \mathbf{C}$} & Salep 5\% & $\mathrm{H}$ & $\mathrm{H}$ & $\mathrm{H}$ & $\mathrm{H}$ & $\mathrm{H}$ & $\mathrm{H}$ \\
\hline & Salep 10\% & $\mathrm{H}$ & $\mathrm{H}$ & $\mathrm{H}$ & $\mathrm{H}$ & $\mathrm{H}$ & $\mathrm{H}$ \\
\hline & Salep $15 \%$ & $\mathrm{H}$ & $\mathrm{H}$ & $\mathrm{H}$ & $\mathrm{H}$ & $\mathrm{H}$ & $\mathrm{H}$ \\
\hline & Kontrol Positif & $\mathrm{H}$ & $\mathrm{H}$ & $\mathrm{H}$ & $\mathrm{H}$ & $\mathrm{H}$ & $\mathrm{H}$ \\
\hline & Kontrol Negatif & $\mathrm{H}$ & $\mathrm{H}$ & $\mathrm{H}$ & $\mathrm{H}$ & $\mathrm{H}$ & $\mathrm{H}$ \\
\hline \multirow[t]{5}{*}{$25^{\circ} \mathrm{C}$} & Salep 5\% & $\mathrm{H}$ & $\mathrm{H}$ & $\mathrm{H}$ & $\mathrm{H}$ & $\mathrm{H}$ & $\mathrm{H}$ \\
\hline & Salep 10\% & $\mathrm{H}$ & $\mathrm{H}$ & $\mathrm{H}$ & $\mathrm{H}$ & $\mathrm{H}$ & $\mathrm{H}$ \\
\hline & Salep $15 \%$ & $\mathrm{H}$ & $\mathrm{H}$ & $\mathrm{H}$ & $\mathrm{H}$ & $\mathrm{H}$ & $\mathrm{H}$ \\
\hline & Kontrol Positif & $\mathrm{H}$ & $\mathrm{H}$ & $\mathrm{H}$ & $\mathrm{H}$ & $\mathrm{H}$ & $\mathrm{H}$ \\
\hline & Kontrol Negatif & $\mathrm{H}$ & $\mathrm{H}$ & $\mathrm{H}$ & $\mathrm{H}$ & $\mathrm{H}$ & $\mathrm{H}$ \\
\hline \multirow[t]{5}{*}{$40^{\circ} \mathrm{C}$} & Salep 5\% & $\mathrm{H}$ & $\mathrm{H}$ & $\mathrm{H}$ & $\mathrm{H}$ & $\mathrm{H}$ & $\mathrm{H}$ \\
\hline & Salep $10 \%$ & $\mathrm{H}$ & $\mathrm{H}$ & $\mathrm{H}$ & $\mathrm{H}$ & $\mathrm{H}$ & $\mathrm{H}$ \\
\hline & Salep $15 \%$ & $\mathrm{H}$ & $\mathrm{H}$ & $\mathrm{H}$ & $\mathrm{H}$ & $\mathrm{H}$ & $\mathrm{H}$ \\
\hline & Kontrol Positif & $\mathrm{H}$ & $\mathrm{H}$ & $\mathrm{H}$ & $\mathrm{H}$ & $\mathrm{H}$ & $\mathrm{H}$ \\
\hline & Kontrol Negatif & $\mathrm{H}$ & $\mathrm{H}$ & $\mathrm{H}$ & $\mathrm{H}$ & $\mathrm{H}$ & $\mathrm{H}$ \\
\hline
\end{tabular}

Adapun syarat sediaan yang baik adalah homogen. Sediaan yang homogen akan memberikan hasil yang baik karena bahan obat terdispersi dalam bahan dasarnya secara merata, sehingga dalam setiap bagian sediaan mengandung bahan obat yang jumlahnya sama. Jika bahan obat tidak terdispersi merata dalam bahan dasarnya maka obat tersebut tidak akan mencapai efek terapi yang diinginkan.

Hasil dari pengujian daya sebar salep dari awal pembuatan sampai minggu ke-4 dapat dilihat pada Gambar 1. 


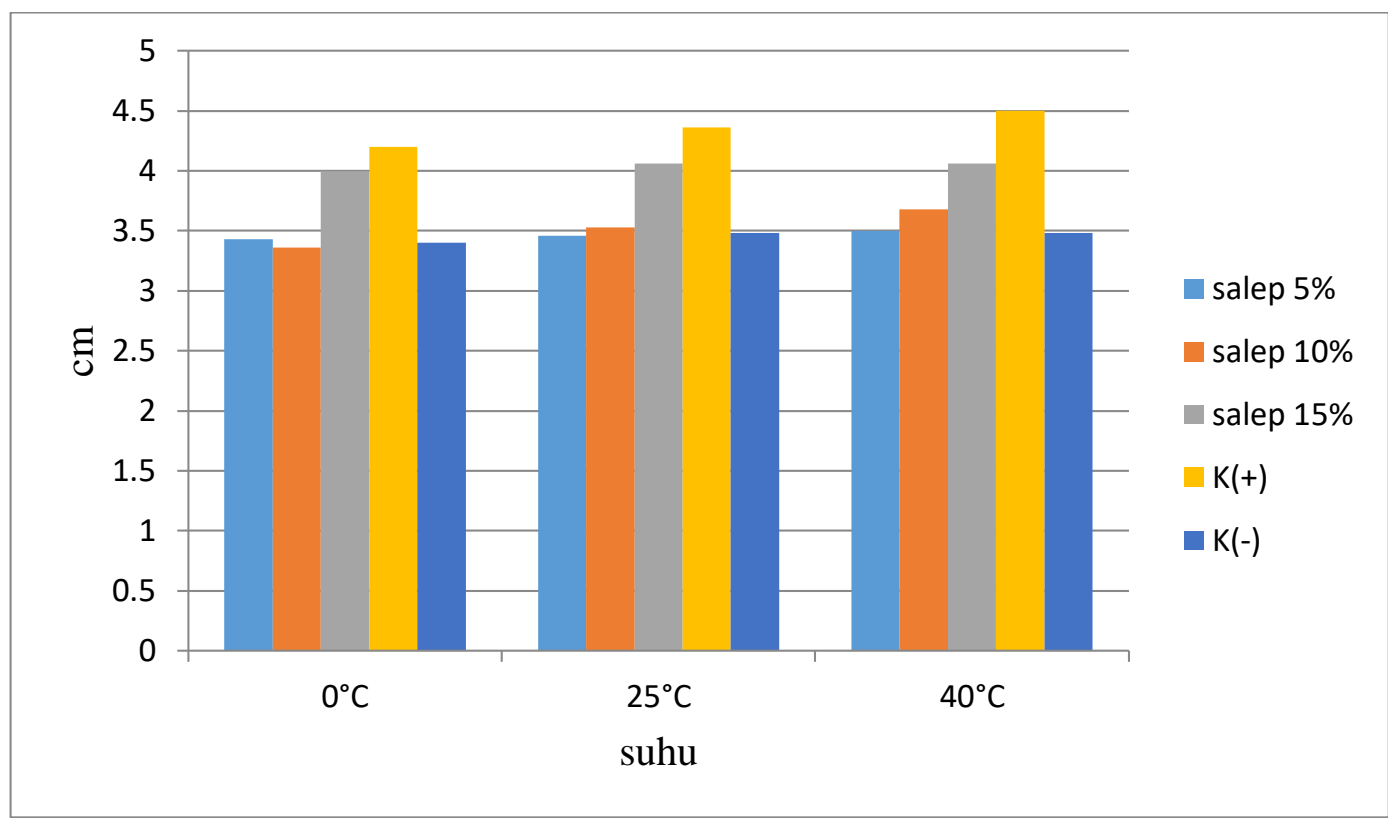

\section{Gambar 1. Grafik Uji Daya Sebar}

Berdasarkan hasil uji daya sebar pada gambar 1. diatas menunjukkan bahwa salep rimpang kencur konsentrasi 15\% dan kontrol positif memiliki daya sebar yang lebih baik dari sediaan basis dan salep rimpang kencur konsentrasi 5\% dan 10\%. Sedangkan persyaratan daya sebar untuk sediaan topikal yaitu sekitar 5-7 cm, maka berdasarkan hasil uji daya sebar pada sediaan dapat dikatakan bahwa sediaan belum memenuhi syarat daya sebar yang baik. Daya sebar yang baik menyebabkan kontak antara obat dengan kulit menjadi luas, sehingga absorpsi obat ke kulit berlangsung cepat. Viskositas suatu sediaan berpengaruh pada luas penyebarannya. Semakin rendah viskositas suatu sediaan maka penyebarannya akan semakin besar sehingga kontak antara obat dengan kulit semakin luas dan absorbsi obat ke kulit akan semakin cepat (Komala, 2015).

Hasil dari pengujian daya lekat salep dari awal pembuatan sampai minggu ke-4 dapat dilihat pada Gambar 2. 


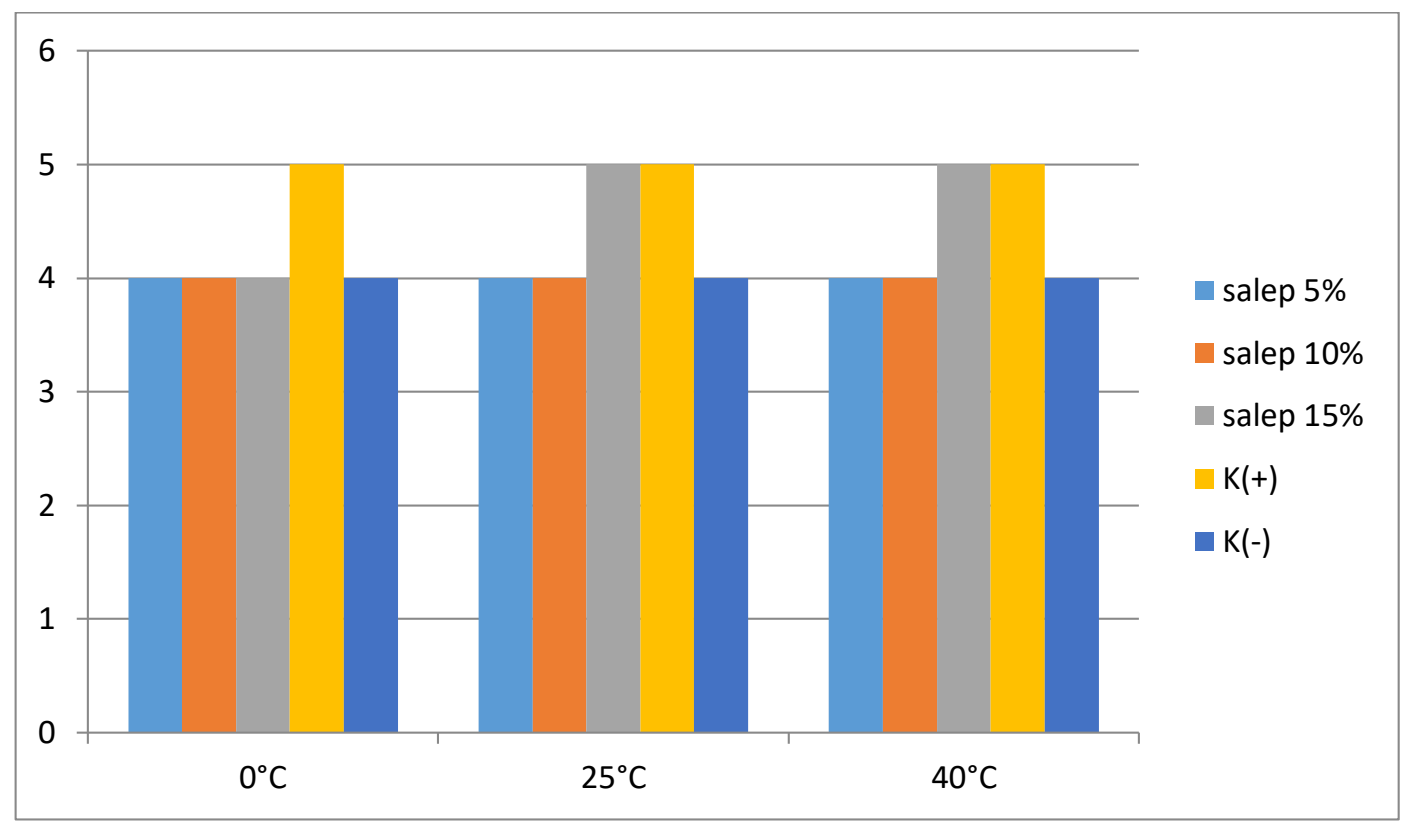

Gambar 2. Grafik Uji Daya Lekat

Berdasarkan hasil uji daya lekat yang dilakukan tiap minggu selama 1 bulan menunjukkan bahwa daya lekat kontrol positif dan salep konsentrasi 15\% selisih 1 detik lebih lama dari konsentrasi 5\%, 10\% dan kontrol negatif. Syarat daya lekat untuk sediaan semi solid adalah tidak kurang dari 4 detik, sehingga sediaan salep rimpang kencur memiliki daya lekat yang baik. Semakin lama salep melekat pada kulit maka efek yang ditimbukan juga semakin besar. Salep dikatakan baik jika daya lekatnya itu besar pada tempat yang diobati (misal kulit), karena obat tidak mudah lepas sehingga dapat menghasilkan efek yang diinginkan.

Berdasarkan indeks iritasi yang didapatkan dari uji iritasi yang dilakukan setelah 72 jam, sediaan salep eksrak rimpang kencur, kontrol negatif dan kontrol positif tidak mengiritasi yang ditunjukkan dari tidak adanya eritema (kemerahan) atau udema (bengkak) pada kulit hewan uji. Hal tersebut dapat dikarenakan kandungan zat aktif dari rimpang kencur itu sendiri yang dapat menekan efek histamin yang dapat menyebabkan reaksi alergi.

Hasil pengamatan uji efektivitas anti inflamasi ekstrak rimpang kencur (Kaempferiae galanga L) terhadap luka sayat pada tikus putih jantan dapat dilihat pada Tabel 3. 
Tabel 3. Uji Efektivitas Anti Inflamasi Salep Ekstrak Rimpang Kencur

\begin{tabular}{|c|c|c|c|c|c|c|c|c|c|c|c|c|c|c|c|}
\hline \multirow{3}{*}{$\begin{array}{c}\text { Hari } \\
\text { Ke } \\
/ \\
\text { hewan } \\
\text { uji }\end{array}$} & \multicolumn{15}{|c|}{ Efek yang dihasilkan } \\
\hline & \multicolumn{3}{|c|}{$\begin{array}{c}\text { Konsentrasi } \\
5 \%\end{array}$} & \multicolumn{3}{|c|}{$\begin{array}{c}\text { Konsentrasi } \\
10 \%\end{array}$} & \multicolumn{3}{|c|}{$\begin{array}{c}\text { Konsentrasi } \\
15 \%\end{array}$} & \multicolumn{3}{|c|}{$\begin{array}{l}\text { Kontrol positif } \\
\text { (Betadine } \\
\text { salep) }\end{array}$} & \multicolumn{3}{|c|}{$\begin{array}{l}\text { Kontrol negatif } \\
\text { (basis salep) }\end{array}$} \\
\hline & I & II & III & I & II & III & I & II & III & I & II & III & I & II & III \\
\hline 1 & 1 & 1 & 1 & 1 & 1 & 1 & 1 & 1 & 1 & 1 & 1 & 1 & 1 & 1 & 1 \\
\hline 2 & 1 & 1 & 1 & 1 & 1 & 1 & 2 & 2 & 2 & 2 & 2 & 2 & 1 & 1 & 1 \\
\hline 3 & 2 & 2 & 2 & 2 & 2 & 2 & 2 & 2 & 2 & 2 & 2 & 2 & 1 & 1 & 2 \\
\hline 4 & 2 & 2 & 2 & 2 & 2 & 2 & 3 & 3 & 2 & 3 & 3 & 3 & 2 & 2 & 2 \\
\hline 5 & 3 & 3 & 3 & 3 & 3 & 3 & 3 & 3 & 3 & 3 & 3 & 3 & 2 & 2 & 2 \\
\hline 6 & 3 & 3 & 3 & 3 & 3 & 3 & 4 & 4 & 3 & 4 & 4 & 4 & 2 & 2 & 2 \\
\hline 7 & 3 & 3 & 3 & 3 & 3 & 3 & & & 4 & & & & 3 & 3 & 2 \\
\hline 8 & 4 & 3 & 4 & 4 & 4 & 4 & & & & & & & 3 & 3 & 3 \\
\hline 9 & & 4 & & & & & & & & & & & 3 & 3 & 3 \\
\hline 10 & & & & & & & & & & & & & 4 & 3 & 3 \\
\hline 11 & & & & & & & & & & & & & & 4 & 4 \\
\hline
\end{tabular}

\section{2}

\begin{tabular}{cccccccccccccccc}
\hline $\begin{array}{c}\text { Jumla } \\
\text { h }\end{array}$ & 19 & 22 & 19 & 19 & 19 & 19 & 15 & 15 & 17 & 15 & 15 & 15 & 22 & 25 & 25 \\
\hline $\begin{array}{c}\text { Rata- } \\
\text { rata }\end{array}$ & 2,3 & 2,4 & 2,3 & 2,3 & 2,3 & 2,3 & 2,5 & 2,5 & 2,4 & 2,5 & 2,5 & 2,5 & 2,2 & 2,2 & 2,2 \\
\end{tabular}

Keterangan :

Merah sekali, basah :nilai 1

Merah, agak basah :nilai 2

Agak merah, hampir kering : nilai 3

Kering (sembuh) :nilai 4

Dari tabel diatas setelah dilakukan pengamatan terhadap luka sayat pada tikus putih jantan dapat dilihat terdapat perbedaan penyembuhan antara konsentrasi salep 5\%, 10\%, 15\%, kontrol positif dan kontrol negatif. Dari konsentrasi 5\% dan 10\% luka sayat dapat kering setelah pengobatan selama 8 hari. sedangkan untuk kontrol positif dan konsentrasi $15 \%$ sudah sembuh pada hari ke 6 dan 7. Untuk kontrol negatif luka dapat sembuh setelah 10 sampai 11 hari.

Syarat suatu data dapat memakai analisis ANAVA yaitu data hasil pengamatan harus homogen dan terdistribusi normal. Berdasarkan analisi ANAVA data hasil pengamatan uji efektivitas anti inflamasi salep ekstrak rimpang kencur adalah homogen dan terdistribusi normal. Uji efektifitas bertujuan untuk mengetahui efektif atau tidaknya 
ekstrak rimpang kencur yang dibuat dalam bentuk sediaan salep untuk penyembuhan inflamasi pada luka sayat tikus putih jantan sekaligus untuk menjawab dari rumusan masalah yang diajukan. Hal tersebut dapat dibuktikan dengan menggunakan perhitungan ANAVA satu arah dan uji t (t-test) untuk menjawab hipotesis yang diajukan.

Berdasarkan hasil dari perhitungan uji anava satu arah dengan taraf nyata $(\alpha=$ $5 \%$ ), diperoleh hasil $\mathrm{F}$ hitung $>\mathrm{F}$ tabel $(3.043>2,450)$ maka H0 ditolak, hal tersebut menunjukan bahwa salep ekstrak rimpang kencur mempunyai efektivitas antiinflamasi terhadap luka sayat hewan uji. Setelah itu dilanjutkan dengan analisis Uji t. Berdasarkan uji t-test diperoleh nilai $\mathrm{T}_{\text {hitung }}$ yang lebih kecil dari $\mathrm{T}_{\text {tabel }}$ adalah untuk salep konsentrasi $5 \%, 10 \%$, dan $15 \%$ yaitu $(0,555<2,019 ; 0,524<2,019 ; 1,374<2,019)$ yang artinya tidak ada perbedaan signifikan antara salep konsentrasi 5\%, 10\% dan 15\% dengan kontrol positif. Sehingga hasilnya menunjukkan bahwa sediaan salep ekstrak rimpang kencur efektif sebagai antiinflamasi pada luka sayat hewan uji.

\section{PENUTUP}

Berdasarkan hasil penelitian uji efektivitas antiinflamasi salep ekstrak rimpang kencur (Kampferiae galanga L) pada luka sayat tikus putih jantan yang telah dilakukan dapat disimpulkan bahwa salep ekstrak rimpang kencur (Kampferiae galanga L) memiliki efektivitas sebagai antiinflamasi pada luka sayat tikus putih jantan dengan konsentrasi $15 \%$ yang paling efektif sebagai antiinflamasi pada luka sayat tikus putih jantan. Untuk hasil uji sifat fisik sediaan salep ekstrak rimpang kencur (Kampferiae galanga L) memberikan hasil yang baik dan memenuhi persyaratan sediaan kecuali daya sebar. Oleh karena itu penulis mengajukan saran yaitu diperlukan penelitian lain dengan metode ekstraksi yang berbeda, misalkan dengan metode destilasi untuk mengetahui minyak atsirinya ataupun pada peneliti selanjutnya untuk mencoba menggunakan bagian lain dari simplisia selain rimpangnya, memformulasikan ekstrak rimpang kencur (Kampferiae galanga L) dalam bentuk sediaan lain, misalnya gel, lotion atau krim, dan untuk lebih mengetahui stabilitas salep yang lebih baik, maka hendaklah dibuat formulasi salep dengan formula yang berbeda serta bahan dan alat yang lebih lengkap lagi sehingga diharapkan stabilitas dapat terlihat lebih jelas dan nyata.

\section{DAFTAR PUSTAKA}


PharmaXplore

Jurnal Sains dan Ilmu Farmasi
ISSN: 2527-5801

Vol. 2 No 3 Mei 2017

Anonim. 1978. Formularium nasional. Edisi II. Depkes RI. Jakarta.

Agoes, Goeswin. 2007. Pengembangan Sediaan Farmasi. Penerbit : ITB Press. Bandung. Asmara A.,Daili SF, Noegrohowati T, Zubaedah I. 2012. Vehikulum Dalam Dermatoterapi Topikal. MDVI Vol 39 No1 halaman 25-35. Departemen Ilmu Farmasi Kedokteran FKUI/RSCM. Jakarta.

Barber, Paul dan Deborah. 2012. Intisari Farmakologi Untuk Perawat. Terjemahan Wuri Praptiani. Penerbit Buku Kedokteran ECG. Jakarta.

Buang, Aryani. 2012. Uji Efek Anti Inflamasi Salep Ekstrak Etanol Rimpang Kunyit (Curcuma domestica rhizoma) Terhadap Mencit (Mus musculus). Media Farmasi Vol IX No 16 halaman 10-14. Politeknik Kesehatan Kemenkes Makassar. Makassar.

Hasanah, Aliya N, Fikri Nazarudin, Ellin Febrina, Ade Zuhrotun. 2011. Analisis Kandungan Minyak Atsiri dan Uji Aktivitas Anti Inflamasi Ekstrak Rimpang Kencur (Kaempferia galangal L.). Jurnal Matematika dan Sains Vol 16 No 3. Program Studi Farmasi Fakultas MIPA ITB. Bandung.

Komala, Delia. Dkk. 2015. Evaluasi Uji Iritasi dan Uji Fisik Sediaan Emulgel Minyak Atsiri Bunga Cengkeh (Syzigium aromaticum). Pharmachiana Vol 5 No 2 halaman 115-120. UGM. Yogyakarta.

Naibaho, Olivia H, Paulina Yamlean, Weny Wiyono. 2013. Pengaruh Basis Salep Terhadap Formulasi Sediaan Salep Ekstrak Daun Kemangi (Ocinum sanctum L.) Pada Kulit Punggung Kelinci Yang Dibuat Infeksi Staphylococus aureus. Pharmacon Jurnal Ilmiah UNSRAT Vol 2 No.2 halaman 27-33. Program Studi Farmasi Fakultas MIPA UNSRAT. Manado.

Narande, Julia M, Anne Wulur, dan Adithya Yudistira. 2013. Uji Efek Anti Inflamasi Ekstrak Etanol Daun Suji (Dracena angustifolia Roxb) Terhadap Edema Kaki Tikus Putih Jantan Galur Wistar. Pharmacon Jurnal Ilmiah Farmasi UNSRAT Vol 2 No 03 halaman 14-18. Program Studi Farmasi Fakultas MIPA UNSRAT. Manado.

Supardi, Sudibyo. 2014. MetodePenelitian Untuk Mahasiswa Farmasi. Cetakan Pertama. CV. Trans Info Media (TIM). Jakarta. 